\title{
Lagos artificiais
}

\section{e ambiente}

No ciclo de necessidades e crises energéticas em que se encontram as nações desenvolvidas e em desenvolvimento, a busca para outras soluções, que não aquelas de utilização de petróleo e seus derivados, é uma realidade que incomoda quando se pensa na sobrevivência do homem, nos moldes estabelecidos pela sociedade de consumo.

A preocupação dos governos e de todos os setores responsáveis, nas nações envolvidas nesta problemática energética, tem sido uma busca constante de fontes alternativas e técnicas para economia de energia.

O Brasil é um país que apresenta condições excepcionais para equacionar os modelos alternativos e que ficam explicitados nos seus planos de desenvolvimento energético, principalmente no que se refere à energia portátil.

As mais diversas equipes de pesquisadores e técnicos têm sido recrutadas pelos organismos do Governo. Das trocas de experiências, das pesquisas realizadas, assim como das análises procedidas, algumas ações foram adotadas. Dentre programas propostos aqueles de maior vulto são o Proalcool e o de aproveitamento da radiação solar em seus mais variados aspectos.

Do ponto de vista da energia hidrelétrica, possuindo a Amazônia um enorme potencial, passou a ser sede de grandes projetos para aproveitamento de seus cursos d'água, tais como: Tucuruí, Balbina, Samuel, Cachoeira da Porteira, Babaquara e Cararaô, entre outros.

Os reservatórios a serem formados variam em área desde $645 \mathrm{~km}^{2}$ (Samuel) até $6.140 \mathrm{~km}^{2}$ (Babaquara).

Existe uma consciência bem estabelecida de que a formação de grandes lagos impõe um impacto ao ambiente. Os problemas existem e as soluções devem ser propostas e viabilizadas.

A ELETRONORTE, com-base em planejamento e política inteligentes e objetivas, tem procurado juntamente com o Conselho Nacional de Desenvolvimento Científico e Tecnológico, incentivar e amparar as pesquisas que se fazem necessárias para a geração do conhecimento técnico-científico, que sirva como base às soluções propostas.

Toda esta problemática está sendo encarada sob os aspectos físico-biológicos e sociais decorrentes

O INPA, com sua participação não só no Projeto Tucuruí mas em todos os demais que se iniciam, se propõe a estudar os fenômenos que expliquem e indiquem soluções para as modificações que, sem dúvida, ocorrerão quer quanto à qualidade da água, à fauna e à flora, assim como o ciclo das doenças endêmicas nestas regiões. 
Os mecanismos de interação entre os fatores do mesoclima devem ser detectados para que se consiga não só as soluções mais econâmicas, como também aquelas indicações mais inteligentes.

A preocupação do Governo Federal através da ELETRONORTE, para a solução de problemas de tamanha importância, permitiu aos profissionais engajados nestes programas de pesquisas a oportunidade de contribuir, com todo o seu idealismo e capacidade amparados em uma real política de desenvolvimento científico e tecnológico.

O INPA, como órgão executor dos projetos, contribuirá efetivamente para o sucesso do esforço que se realiza, visando o aproveitamento das riquezas regionais dentro de uma política de conservação e exploração sustentada do ambiente.

Jesus Marden dos Santos

Coordenador do Projeto Tucuruí 